\title{
Foliar Application of Fish Amino Acid and Egg Amino Acid to Improve the Physiological Parameters of Rice
}

\author{
B. Priyanka ${ }^{1 *}$, T. Ramesh $^{1}$, S. Rathika ${ }^{1}$ and P. Balasubramaniam ${ }^{2}$ \\ ${ }^{1}$ Department of Agronomy, ${ }^{2}$ Department of Soil Science and Agricultural Chemistry, Anbil \\ Dharmalingam Agricultural College \& Research Institute, Tiruchirapalli - 620 027, India \\ *Corresponding author
}

\section{Keywords}

Fish amino acid, Egg amino acid, Recommended dose of fertilizers, LAI, Total chlorophyll, Soluble protein, CGR and yield

Article Info

Accepted:

22 January 2019

Available Online:

10 February 2019

\section{A B S T R A C T}

A field experiment was conducted at Anbil Dharmalingam Agricultural College and Research Institute, Tiruchirappalli to study the effect of fish amino acid and egg amino acid as foliar application to increase the Physiological parameters of rice during 20162017. The experiment was laid out in Randomized block design (RBD) with three replications and eleven treatments viz., recommended dose of fertilizers (187.5:50:50 kg NPK ha $\left.{ }^{-1}\right)\left(\mathrm{T}_{1}\right)$, foliar spray of egg amino acid $0.5 \%\left(\mathrm{~T}_{2}\right)$, egg amino acid $1.0 \%$, egg amino acid $1.5 \%\left(\mathrm{~T}_{3}\right)$, fish amino acid $0.5 \%\left(\mathrm{~T}_{4}\right)$, fish amino acid $1.0 \%\left(\mathrm{~T}_{5}\right)$, fish amino acid $1.5 \%\left(\mathrm{~T}_{6}\right)$, recommended dose of fertilizers + egg amino acid $0.5 \%\left(\mathrm{~T}_{7}\right)$, recommended dose of fertilizers + egg amino acid $1.0 \%\left(\mathrm{~T}_{8}\right)$, recommended dose of fertilizers + fish amino acid $0.5 \%\left(\mathrm{~T}_{10}\right)$ and recommended dose of fertilizers + fish amino acid $1.0 \%\left(\mathrm{~T}_{11}\right)$. The result revealed that foliar spray of egg amino acid $1.0 \%$ increased the LAI, total chlorophyll, soluble protein and yield significantly than recommended dose of fertilizers. Foliar spray of fish amino acid $1.0 \%+$ recommended dose of fertilizers increased the CGR.

\section{Introduction}

Rice (Oryza sativa L.) is one of the cereal crops of great significance in world and primary staple food for huge population in Asia, Africa and Latin America. Consumption of rice accounts for over 90 per cent of the world's population in Asia. China, India and Indonesia are producing 30.85 per cent, 20.12 per cent and 8.21 per cent, respectively of total global rice production (Anonymous,
2012; Kadu et al., 2015). Organic farming is responsible for enhanced crop production with a minimal environmental load with keeping ecological balance, contains the general meaning of the holistic production and management system for enhancing health of agricultural ecosystem (Otto Schmid, 2003). In organic rice cultivation, various external indigenous technical knowledge (ITK's) including organic preparations viz., panchakavya, amirthakaraisal, amrithpani, 
fish amino acid (FAA), egg amino acid (EAA) and vermiwash etc., are being used for improving the crop growth and development. Application of egg lime mix with panchakavya on crops such as paddy, wheat, banana, vegetables, greens and fruit trees remarkably increased the yield and longevity of the plants (Prabu, 2008).

\section{Materials and Methods}

A field experiment was laid out with different concentration of fish amino acid and egg amino acid along with RDF during 2016 2017 in clay loam soil at Anbil Dharmalingam Agricultural College and Research Institute, Tiruchirappalli in randomized block design with three replications. The treatments were recommended dose of fertilizers (187.5:50:50 $\mathrm{kg}$ NPK ha $\left.{ }^{-1}\right)\left(\mathrm{T}_{1}\right)$, foliar spray of egg amino acid $0.5 \%\left(\mathrm{~T}_{2}\right), 1.0 \%\left(\mathrm{~T}_{3}\right)$ and $1.5 \%\left(\mathrm{~T}_{4}\right)$, foliar spray of fish amino acid $0.5 \%\left(\mathrm{~T}_{5}\right), 1.0$ $\%\left(\mathrm{~T}_{6}\right)$ and $1.5 \%\left(\mathrm{~T}_{7}\right)$, recommended dose of fertilizers + egg amino acid $0.5 \%\left(\mathrm{~T}_{8}\right)$, recommended dose of fertilizers + egg amino acid $1.0 \%\left(\mathrm{~T}_{9}\right)$, recommended dose of fertilizers + fish amino acid $0.5 \%\left(\mathrm{~T}_{10}\right)$ and recommended dose of fertilizers + fish amino acid $1.0 \%\left(\mathrm{~T}_{11}\right)$. Foliar spraying of fish amino acid and egg amino acid was done at Tillering (25 DAT), Panicle initiation (45 DAT) and Flowering stages (60 DAT).

Foliar spray of fish amino acid and egg amino acid along with recommended dose of fertilizers recorded LAI, Soluble Protein, Total Chlorophyll and grain yield and straw yield of rice.

\section{Preparation of egg amino acid}

Twenty numbers of ripened lemon was squeezed and the juice was taken in a plastic container. Then 10 numbers of eggs kept inside the lemon juice till the eggs were soaked completely and kept for 10 days. After 10 days, eggs were smashed well and $250 \mathrm{~g}$ jaggery was added and kept for 10 days. The content was filtered after 10 days and the liquid portion was collected and stored in separate container for foliar spray (Anonymous, 2015).

\section{Preparation of fish amino acid}

Fish amino acid was prepared from fish waste obtained from local fish market. Equal amount of fish waste and jaggery were taken ( $1 \mathrm{~kg}$ of each fish waste and jaggery). The fish waste was taken an air tight plastic jar/bottle and jaggery was added. The materials were mixed well and stored in a cool dry place. It was kept away from direct sun light. After 10 days, the liquid portion was filtered and used for spraying (Maghirang, 2011). The final product was viscous fluid and had smell of panchamirtham. Plant samples were estimated by standard procedure. The data were statistically analyzed and results are discussed.

\section{Results and Discussion}

Foliar spray of fish amino acid and egg amino acid along with recommended dose of fertilizer had significantly led to higher LAI, total chlorophyll, CGR, Soluble protein and yield (Table 1). Higher LAI of 4.5 was obtained in recommended dose of fertilizers + foliar spray of fish amino acid $1.0 \%$ and it was comparable with recommended dose of fertilizers + foliar spray of egg amino acid 1.0 $\%\left(\mathrm{~T}_{9}\right)$, recommended dose of fertilizers + foliar spray of fish amino acid $0.5 \%\left(\mathrm{~T}_{10}\right)$ and recommended dose of fertilizers + foliar spray of egg amino acid $0.5 \%\left(\mathrm{~T}_{8}\right)$. Lower LAI of 3.5 was recorded with egg amino acid $1.5 \%$ alone $\left(\mathrm{T}_{4}\right)$. Significantly higher crop growth rate of $13.5 \mathrm{~g} \mathrm{~m}^{-2}$ day $^{-1}$ was noticed under recommended dose of fertilizers + foliar spray 
of fish amino acid $1.0 \%\left(\mathrm{~T}_{11}\right)$ at flowering to harvest stage. This was comparable with recommended dose of fertilizers + foliar spray of fish amino acid $0.5 \%\left(\mathrm{~T}_{10}\right)$, recommended dose of fertilizers + foliar spray of egg amino acid $1.0 \%\left(\mathrm{~T}_{9}\right)$, recommended dose of fertilizers + foliar spray of egg amino acid 0.5 $\%\left(\mathrm{~T}_{8}\right)$ and recommended dose of fertilizers alone $\left(\mathrm{T}_{1}\right)$. Lower crop growth rate of $8.1 \mathrm{~g} \mathrm{~m}^{-}$ ${ }^{2}$ day $^{-1}$ was recorded under egg amino acid 1.5 $\%$ alone $\left(\mathrm{T}_{4}\right)$. Significantly higher chlorophyll content of $5.8 \mathrm{mg} \mathrm{g}^{-1}$ was obtained with recommended dose of fertilizers + foliar spray of egg amino acid $1.0 \%\left(\mathrm{~T}_{9}\right)$ at flowering stages. However, it was comparable with recommended dose of fertilizers + foliar spray of fish amino acid $1.0 \%\left(\mathrm{~T}_{11}\right)$. Foliar spray of egg amino acid $0.5 \%\left(\mathrm{~T}_{2}\right)$ recorded lesser chlorophyll content of $3.9 \mathrm{mg} \mathrm{g}^{-1}$ at flowering stages. Significantly higher soluble protein content $\left(57.7 \mathrm{mg} \mathrm{g}^{-1}\right)$ was registered under recommended dose of fertilizers + foliar spray of egg amino acid $1.0 \% \quad\left(\mathrm{~T}_{9}\right)$ during flowering stage. This was comparable with recommended dose of fertilizers + foliar spray of egg amino acid $0.5 \%\left(\mathrm{~T}_{8}\right)$. Soluble protein content $\left(35.7 \mathrm{mg} \mathrm{g}^{-1}\right)$ was lesser under egg amino acid $1.5 \%$ alone $\left(\mathrm{T}_{4}\right)$.

Table.1 Effect of fish amino acid and egg amino acid foliar spray along with recommended dose of fertilizers on LAI, CGR, total chlorophyll, soluble protein and yield of rice

\begin{tabular}{|c|c|c|c|c|c|}
\hline Treatments & LAI & $\begin{array}{c}\text { CGR (kg } \\
\left.\text { ha }^{-1}\right)\end{array}$ & $\begin{array}{c}\text { Total } \\
\text { chlorophyll } \\
\left(\mathbf{m g ~ g}^{-1}\right)\end{array}$ & $\begin{array}{c}\text { Soluble } \\
\text { protein }(m g \\
\left.\mathbf{g}^{-1}\right)\end{array}$ & $\begin{array}{c}\text { Grain yield } \\
\left(\mathrm{kg} \mathrm{ha}^{-1}\right)\end{array}$ \\
\hline $\begin{array}{l}T_{1} \text { - Recommended Dose } \\
\text { of Fertilizers (RDF) } \\
\left(187.5: 50: 50 \mathrm{~kg} \mathrm{NPK} \mathrm{ha}^{-1}\right)\end{array}$ & 4.2 & 12.4 & 4.3 & 45.3 & 3870 \\
\hline $\begin{array}{l}\mathrm{T}_{2} \text { - Egg Amino Acid } 0.5 \\
\%\end{array}$ & 3.6 & 9.8 & 3.9 & 43.7 & 2855 \\
\hline $\begin{array}{l}\text { T }_{3}-\text { Egg Amino Acid } 1.0 \\
\%\end{array}$ & 3.8 & 9.2 & 4.6 & 44.3 & 3005 \\
\hline $\begin{array}{l}\text { T }_{4-} \text { Egg Amino Acid } 1.5 \\
\%\end{array}$ & 3.5 & 8.1 & 4.4 & 35.7 & 2780 \\
\hline $\begin{array}{l}\mathrm{T}_{5^{-}} \text {Fish Amino Acid } 0.5 \\
\%\end{array}$ & 3.8 & 10.2 & 4.5 & 39.3 & 2996 \\
\hline $\begin{array}{l}\mathrm{T}_{6}-\text { Fish Amino Acid } 1.0 \\
\%\end{array}$ & 4.1 & 11.2 & 4.7 & 44.3 & 3127 \\
\hline $\begin{array}{l}\mathrm{T}_{7-} \text { Fish Amino Acid } 1.5 \\
\%\end{array}$ & 3.9 & 8.6 & 4.5 & 40.7 & 2846 \\
\hline $\begin{array}{l}\text { T }_{8}-\text { RDF + Egg Amino } \\
\text { Acid } 0.5 \%\end{array}$ & 4.2 & 12.6 & 5.1 & 56.7 & 4610 \\
\hline $\begin{array}{l}\text { T9- RDF + Egg Amino }_{9} \\
\text { Acid } 1.0 \%\end{array}$ & 4.4 & 12.8 & 5.8 & 57.7 & 4763 \\
\hline $\begin{array}{l}\mathrm{T}_{10}-\mathrm{RDF}+\text { Fish Amino } \\
\text { Acid } 0.5 \%\end{array}$ & 4.1 & 13.1 & 5.0 & 46.0 & 4355 \\
\hline $\begin{array}{l}T_{11}-\text { RDF + Fish Amino } \\
\text { Acid } 1.0 \%\end{array}$ & 4.5 & 13.5 & 5.5 & 46.7 & 4471 \\
\hline SEd & 0.17 & 0.9 & 0.28 & 2.91 & 222 \\
\hline $\mathrm{CD}(\mathbf{P}=\mathbf{0 . 0 5})$ & 0.37 & 1.9 & 0.59 & 6.07 & 462 \\
\hline
\end{tabular}


Fig.1 Effect of fish amino acid and egg amino acid foliar spray on total chlorophyll content (mg $\left.\mathrm{g}^{-1}\right)$ at flowering stage

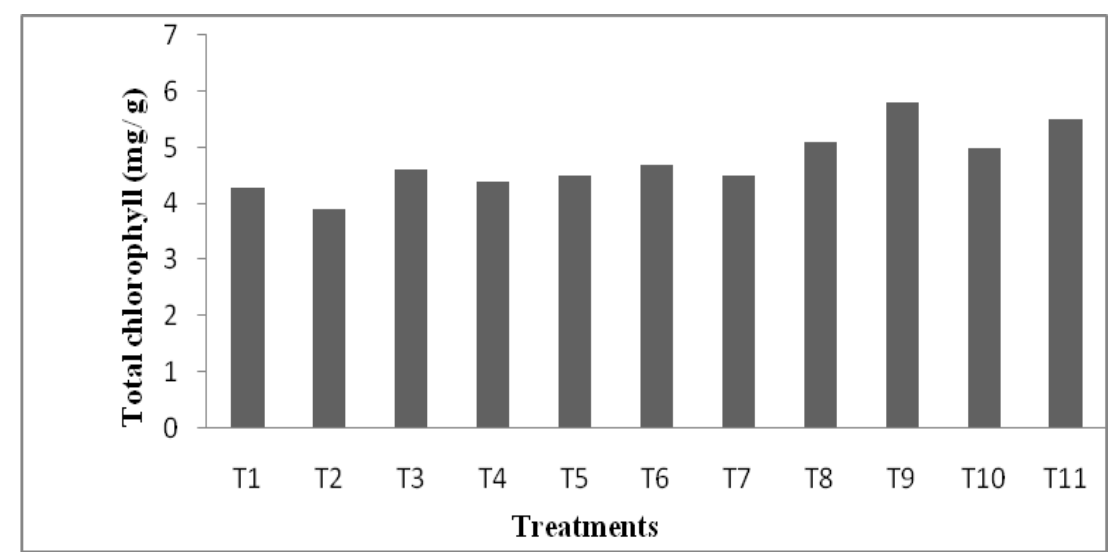

Recommended dose of fertilizers recorded higher values of physiological parameters such as LAI and chlorophyll content than foliar spray alone. This might be due to higher nutrient availability and better uptake of nutrients resulted in increased LAI and plant height with better photosynthesis activity and accumulation (Rather et al., 2003). Foliar spray alone recorded the lowest physiological parameters mainly because of foliar spray alone did not supply enough nutrients to the plants, which would have reduced the LAI. The relative increase in crop growth rate was due to higher supply of nutrients from the soil applied recommended dose of fertilizers and foliar spray of egg amino acid to the growing tissues which resulted in more leaf area and radiation use efficiency might have led to higher photo assimilate production and thus increased the CGR (Naing et al., 2010). Application of recommended dose of fertilizers + foliar spray of egg amino acid 1.0 $\%$ registered 27.3 per cent significantly higher soluble protein than recommended dose of fertilizers alone. The relative increase in soluble protein content might be due to supply of higher nutrients especially nitrogen and micronutrients to the growing tissues which led to the synthesis of soluble protein. Among the different concentration of foliar spray egg amino acid $1.0 \%+$ recommended dose of fertilizer recorded high yield of $4763 \mathrm{~kg} \mathrm{ha}^{-1}$. Yield increase was 23 per cent over recommended dose of fertilizers alone. Yield increase due to Quick absorption and assimilate of more nitrogen, phosphorous, potassium and micro nutrients present in the egg amino acid and fish amino acid through foliar spray at tillering, panicle initiation and flowering stages would have improved the metabolic activity and cell division resulting in higher plant height, more number of leaves, more chlorophyll content which consequently increased the photosynthetic activity which in turn yield attribute and higher grain yield of rice (Abbasi et al., 2003) (Fig. 1). The lowest yield $\left(2780 \mathrm{~kg} \mathrm{ha}^{-1}\right)$ was recorded in egg amino acid $1.5 \%$ alone in which foliar spray of egg amino acid alone may not be sufficient to supply required nutrients to the plants, which would have reduced the tiller production, leaf area and yield attributes and finally yield of rice.

It could be concluded that foliar spray of fish amino acid or egg amino acid along with recommended dose of fertilizers significantly influenced the various physiological parameters and yield of rice under sodic soil condition. Foliar spray alone did not supply enough nutrients to crop growth, resulting in lower grain yield. Hence, recommended dose 
of fertilizers + foliar spray of egg amino acid $1.0 \%$ could be recommended for yield enhancement in rice under sodic soil condition.

\section{References}

Abbasi, P. A, D. A. Cuppels and G. Lazarovits. 2003. Effect of foliar applications of neem oil and fish emulsion on bacterial spot and yield of tomato and pepper. Can. J. Plant Pathol., 25(1): 41-48.

Anonymous. 2015. Manures - Egg Lime Formulation (Muttai Rasam). Agriculture for Everybody. http://agricultureforeverybody.blogspo t.in

Anonymous. 2012. USDA, Rice OutlookEconomic Research Service publication. USA.

Kadu,T. P., S.S. Kale, N.R. Chayan., T. Agarwal and S. B. Verulkar. 2015. Pyramiding of three bacterial blight resistance in Dubraj rice cultivar using marker-assisted selection. The
Ecoscan., 7: 7-12.

Maghirang, R. G. 2011. Organic Fertilizers from Farm Waste Adopted by Farmers in the Philippines. http://www.agnet.org/library

Naing, A., P. Banterng., A. Polthanee and V. Trelo-Ges. 2010. The effect of different fertilizers management strategies on growth and yield of upland black glutinous rice and soil property. Asian Journal of Plant Sciences, 9: 414-422.

Otto Schmid. 2003. Codex alimentarius. In: The world of organic agriculturestatistics and future prospects (eds. Minou Yussefi and Helga Willer), IFOAM. pp. 41-44.

Prabu, M. J. 2008. Muttai rasam: An excellent plant growth promoter. (Sci \& Tech). Tamil nadu. The Hindu, 18.9.2008.

Rather, S. A., N. Ahmed and M.S. Chatto. 2003. Response of onion to microbial inoculation and chemical nitrogen. $J$. Horti. Sci., 33(3\&8): 270-271.

\section{How to cite this article:}

Priyanka, B., T. Ramesh, S. Rathika and Balasubramaniam, P. 2019. Foliar Application of Fish Amino Acid and Egg Amino Acid to Improve the Physiological Parameters of Rice. Int.J.Curr.Microbiol.App.Sci. 8(02): 3005-3009. doi: https://doi.org/10.20546/ijcmas.2019.802.351 